\title{
Biotransformation of cyclocanthogenol by the endophytic fungus Alternaria eureka 1E1BL1
}

\author{
Güner Ekiz a, Seda Duman ${ }^{\mathrm{b}}$, Erdal Bedir ${ }^{\mathrm{b}}$, * \\ a Department of Pharmacognosy, Faculty of Pharmacy, Near East University, Nicosia, Mersin 10, Turkey \\ b Department of Bioengineering, Faculty of Engineering, Izmir Institute of Technology, 35430 Urla-Izmir, Turkey
}

\section{A R T I C L E I N F O}

\section{Article history:}

Received 15 November 2017

Received in revised form

31 March 2018

Accepted 9 April 2018

Available online 17 April 2018

Keywords:

Astragalus

Fabaceae

Biotransformation

Cycloartanes

Cyclocanthogenol

Endophytic fungus

Alternaria eureka

\begin{abstract}
A B S T R A C T
The microbial transformation of cyclocanthogenol (CCG), Astragalus sp. originated sapogenin, by the endophytic fungus Alternaria eureka 1E1BL1 isolated from Astragalus angustifolius was investigated. Hydroxylation, oxidation, epoxidation, $\mathrm{O}$-methylation, ring-expansion and methyl migration reactions were observed on the triterpenoid skeleton. As a result, eight metabolites were isolated and the structures of the previously undescribed compounds were established by 1-D, 2-D NMR and HR-MS analyses.
\end{abstract} (C) 2018 Elsevier Ltd. All rights reserved.

\section{Introduction}

Biotransformation is chemical modifications that occur when enzymes or whole cell systems are used as catalysts (Borges et al., 2009; de Carvalho, 2011, 2016). This is a useful method for production of new potent molecules, overcoming the problems associated with chemical synthesis reactions/enhancement of the productivity and providing the basic information needed to elucidate the biosynthetic pathways. Producing large amounts of biomass and having great enzyme diversity with chemo-, regioand enantio-selective catalytic abilities make microbial systems logical choice for biotransformation studies (Carballeira et al., 2009; Pimentel et al., 2011; Tao and Xu, 2009). Whole-cell biocatalysis is expected to play a significant role in this growing area of pharmaceutical industry (Lam, 2009). According to the literature, microbial transformation is one of the most commonly used method for transformation of saponins to obtain more active derivatives (Shah et al., 2014; Vincken et al., 2007). Filamentous fungi have been one of the most studied whole cell systems for biotransformation reactions. Recently, endophytic fungi have

\footnotetext{
* Corresponding author.

E-mail address: erdalbedir@iyte.edu.tr (E. Bedir).
}

received great attention due to their ability to transform complex natural products with a high degree of stereospecificity. Considering the fact that endophytes continuously interact with their hosts via special enzymes and chemicals, they may be promising source of biocatalyst with numerous application (Bianchini et al., 2015; Borges et al., 2009; Ludwig-Müller, 2015; Wang and Dai, 2011). However, utilization of the plants' own endophytes to transform plants' own secondary metabolites have been scarcely explored in the field of biotransformation.

The genus Astragalus (Fabaceae) is one of the richest sources of cycloartanes, the unique triterpenoids with a characteristic 9,19cyclopropane ring. Cycloartane-type saponins from Astragalus species have exhibited wide range of biological activities including wound healing, immunomodulatory, antineoplastic, hepatoprotective, antimutagenic, antiviral and antiprotozoal activities (Çalış et al., 1997; Özipek et al., 2005; Nalbantsoy et al., 2011). Cycloastragenol, the main sapogenol of many cycloartane-type glycosides found in Astragalus genus, has attracted great attention as a telomerase activator which was discovered in a systematic screening studies of natural product extracts from traditional Chinese medicines (Harley et al., 2010).

Not only potency of cyloartanes as telomerase activators but also the absence of endophytic fungi's utilization in biotransformation 
prompted us to make an attempt to generate a chemical library. In continuation of our previous efforts (Kuban et al., 2010, 2013; Tağ et al., 2012; Bedir et al., 2015), we performed microbial transformation on Astragalus cycloartanes by using endophytic fungi isolated from Astragalus species. In this study, cyclocanthogenol (CCG), one of the major sapogenins in Astragalus genus, was subjected to biotransformation by fungal endophyte Alternaria eureka (Pleosporaceae) 1E1BL1. Herein, we report isolation and structural elucidation of eight (1-8) biotransformation products with diverse chemistry.

\section{Results and discussion}

A total of 15 endophytic fungi, isolated from the roots, stems and leaves of Astragalus plants, were screened by TLC for their ability to transform CCG into previously undescribed derivatives. Based on the preliminary screening results, the endophytic isolate identified as Alternaria eureka 1E1BL1 was selected for further biotransformation studies. Analytical scale biotransformation was performed to determine the optimal harvesting time of the fungus for transformation of the starting compound. Preparative scale biotransformation of CCG with A. eureka 1E1BL1 for 10 days yielded seven previously undescribed metabolites 1-7, along with the known compound $\mathbf{8}$ (Fig. 1). The structures of $\mathbf{1 - 8}$ were characterized by HR-MS, 1D-, and 2D-NMR data.

Compounds 1, 2 and $\mathbf{3}$ were monohydroxylated products of CCG.
The HR-MS data of compound $\mathbf{1}\left(\mathrm{m} / z 531.3664[\mathrm{M}+\mathrm{Na}]^{+}\right.$, calcd for $\mathrm{C}_{30} \mathrm{H}_{52} \mathrm{O}_{6} \mathrm{Na}$, 531.3661) supported a molecular formula $\mathrm{C}_{30} \mathrm{H}_{52} \mathrm{O}_{6}$, implying a monohydroxylation of the starting compound. In the ${ }^{1} \mathrm{H}$ NMR spectrum, the AX system signals of cyclopropane ring, seven methyl groups in the up-field region, and the characteristic signals belonging to the $\mathrm{H}-3, \mathrm{H}-6, \mathrm{H}-16$ and $\mathrm{H}-24$ oxymethine protons in the low-field displayed no significant discrepancy compared to CCG. Apart from the characteristic low-field signals, an additional oxymethine signal at $\delta 3.82$ was observed corresponding to a carbon at $\delta 73.7$ in the HSQC spectrum. The ${ }^{13} \mathrm{C}$ NMR spectrum of $\mathbf{1}$ showed that C-11 ( $\delta$ 39.7) and C-13 ( $\delta$ 50.5) signals had undergone a significant down-field shift (ca. 16 and 5 ppm, respectively) when compared to that of CCG, suggesting a hydroxylation at C-12 position. This assumption was confirmed with the long-distance correlations in the HMBC spectrum from $\delta 3.82$ to C-13, C-14 and C-18, and $\mathrm{H}-11$ and $\mathrm{H}-18$ to $\delta$ 73.7. In order to establish the stereochemistry at C-12, a 2D-NOESY experiment was performed. The nOe correlation between $\mathrm{H}-12$ and $\beta$-oriented $\mathrm{H}_{3}-18$ indicated the $\alpha$-configuration of $12-\mathrm{OH}$. On the basis of these results, the structure of 1 was established as $3 \beta, 6 \alpha, 12 \alpha, 16 \beta, 24(S), 25-$ hexahydroxycycloartane.

The HR-MS spectrum of $\mathbf{2}$ showed a major ion peak at $\mathrm{m} / \mathrm{z}$ $531.3679[\mathrm{M}+\mathrm{Na}]^{+}\left(\mathrm{C}_{30} \mathrm{H}_{52} \mathrm{O}_{6} \mathrm{Na}\right)$. Like 1, compound 2 displayed the 9,19-cyclopropane ring signals of CCG, seven methyl groups, and the signals belonging to the $\mathrm{H}-3, \mathrm{H}-6, \mathrm{H}-16$ and $\mathrm{H}-24$ oxymethine protons. The signal observed at $\delta 4.04$ suggested another

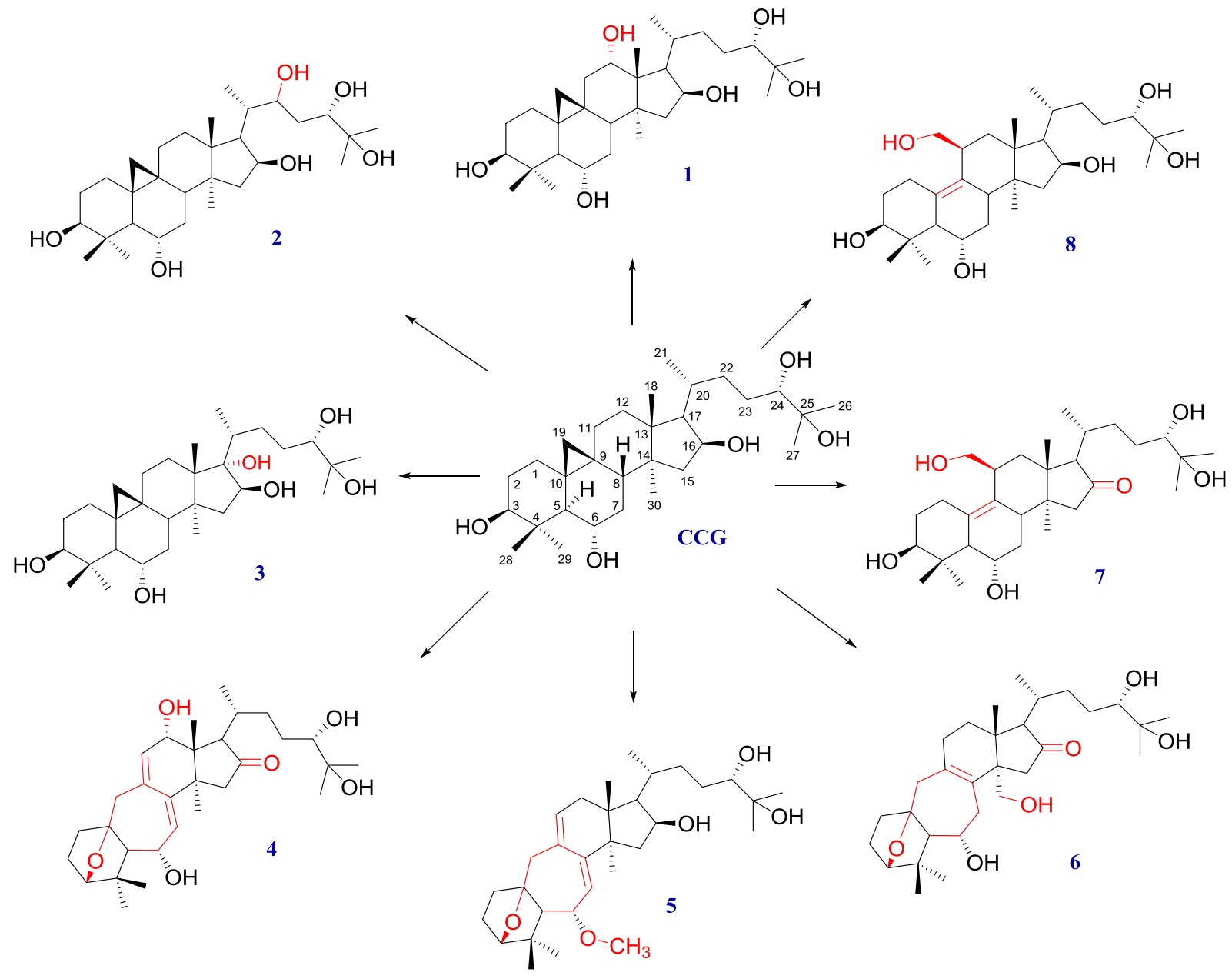

Fig. 1. Transformation products of cyclocanthogenol (CCG). 
oxymethine group corresponding to a carbon at $\delta 75.3$ in the HSQC spectrum. A detailed inspection of the ${ }^{13} \mathrm{C}$ NMR spectrum showed down-field shift for C-20 and C-23 signals (ca. $12 \mathrm{ppm}$ ) when compared to that of CCG, therefore, a hydroxylation at C-22 was suggested. In the COSY spectrum, the partial identification of the side-chain spin system starting from the distinct $\mathrm{H}-24$ proved this suggestion $\left[\mathrm{H}-24(\delta 3.53 \mathrm{dd}, J=10.5,2.2 \mathrm{~Hz}) \rightarrow \mathrm{H}_{2}-23(1.58 \mathrm{~m}\right.$, $1.77 \mathrm{~m}) \rightarrow \mathrm{H}-22(\delta 4.04 \mathrm{dd}, J=7.3,5.8 \mathrm{~Hz})$ ] (Fig. 2). Furthermore, the key long correlations observed in the HMBC spectrum from $\mathrm{H}-22$ to $\mathrm{C}-24$, and from $\mathrm{H}-21 / \mathrm{H}_{2}-23$ to $\mathrm{C}-22$ justified the hydroxylation at $\mathrm{C}$ 22. Based on the NOESY data, one of the intriguing observation in the COSY spectrum was missing ${ }^{3} J_{\mathrm{H}-\mathrm{H}}$ coupling between $\mathrm{H}-22$ and $\mathrm{H}-20$. This data implied that somehow the side chain was not freely rotating to adopt different conformers setting the dihedral angle of the $\mathrm{H}-20 / \mathrm{C}-20 / \mathrm{C}-22 / \mathrm{H}-20$ system to be about $90^{\circ}$. Therefore it was proposed that the conformational flexibility was prohibited due to a couple of hydrogen bond formations in a hydroxyl group rich vicinity (C-16, C-22, C-24 and C-25). To confirm this hypothesis and stereochemistry of C-22, minimized energy conformers of $\mathbf{2}$ were calculated by MM2 molecular mechanics program. Although an appropriate dihedral bond angle was reached with $22(S)$ absolute configuration revealing hydrogen bonds between side chain $\mathrm{OH}$ groups $[\mathrm{C}-22(\mathrm{OH}) / \mathrm{C} 24(\mathrm{OH})$ and $\mathrm{C}-24(\mathrm{OH}) / \mathrm{C} 25(\mathrm{OH})]$, the observed ROESY correlations did imply free rotation in the side chain. The determination of the configuration of the stereocenter C-22 was not possible. On the basis of these results, the structure of 2 was established as $3 \beta, 6 \alpha, 16 \beta, 22,24(S), 25$-hexahydroxycycloartane.

The HR-MS data of compound $3\left(\mathrm{~m} / z 531.3672[\mathrm{M}+\mathrm{Na}]^{+}\right.$, calcd for $\mathrm{C}_{30} \mathrm{H}_{52} \mathrm{O}_{6} \mathrm{Na}$, 531.3661) displayed $16 \mathrm{amu}$ increase over the starting compound, implying monohydroxylation. The signals of 9,19-cyclopropane ring and seven methyl groups, and H-3, H-6, H16 and $\mathrm{H}-24$ resonances were observed readily in the ${ }^{1} \mathrm{H}$ NMR spectrum as in $\mathbf{1}$ and $\mathbf{2}$. In the ${ }^{13} \mathrm{C}$ NMR spectrum, apart from the C$3, \mathrm{C}-6, \mathrm{C}-16, \mathrm{C}-24$ and C-25 oxygenated carbons, an additional signal at $\delta 89.3$ was observed. In the HSQC spectrum, no correlation of this carbon with any proton indicated its quaternary nature. The $\delta 89.3$ resonance was unambiguously assigned to $C-17$ based on the long-distance correlations in the HMBC from $\mathrm{H}-16, \mathrm{H}-15 \mathrm{a}, \mathrm{H}_{3}-18$ and $\mathrm{H}_{3}-21$ protons to $\delta 89.3$ (Fig. 3). Additionally, down-field shifts of C-16, C-14 and C-20 signals substantiated the hydroxylation position. A thorough literature search on biotransformation metabolites of the steroidal compounds proposed a single configuration for $\mathrm{C}-17(\mathrm{OH})$ to be alpha. However, to establish the orientation unambiguously, NMR spectrum of $\mathbf{3}$ was recorded in pyridine- $d_{5}$ to observe the exchangeable proton of $\mathrm{C}-17(\mathrm{OH})$. Based on the ${ }^{3} J_{\mathrm{C}-\mathrm{H}}$ HMBC correlations between the exchangeable proton at $\delta 4.83(\mathrm{~s})$ and $\mathrm{C}-16 / \mathrm{C}-13,17(\mathrm{OH})$ was readily located. In the 2D-ROESY spectrum, cross peaks from this exchangeable proton to the axial $\mathrm{H}-12 \alpha$

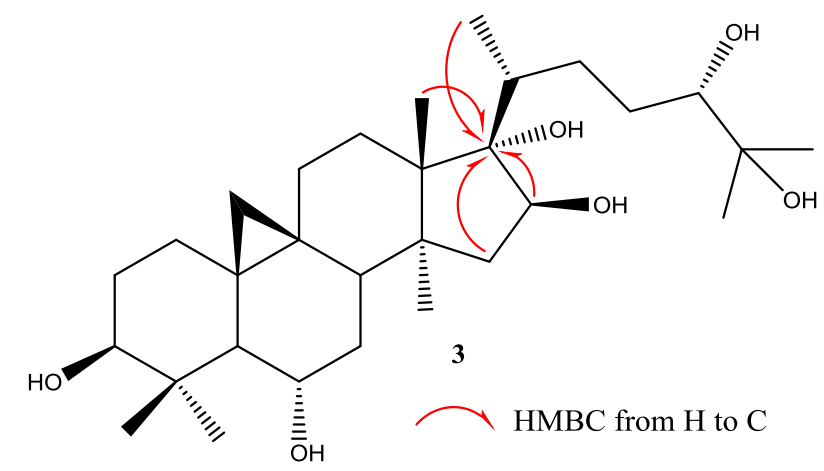

Fig. 3. Key long-range correlations (HMBC) of $\mathbf{3}$.

proton $\left(\delta 2.58, \mathrm{t}, 11.8 \mathrm{~Hz}\right.$ ), and from the latter to $\mathrm{H}_{3}-30$ exhibited that all these protons were cofacial with alpha orientation. Thus, the structure of 3 was identified as $3 \beta, 6 \alpha, 16 \beta, 17 \alpha, 24(S), 25-$ hexahydroxycycloartane.

The molecular formula of compound $\mathbf{4}$ was established as $\mathrm{C}_{30} \mathrm{H}_{46} \mathrm{O}_{6}$ by HR-MS analysis $\left(\mathrm{m} / z 525.3206[\mathrm{M}+\mathrm{Na}]^{+}\right.$, calcd for $\mathrm{C}_{30} \mathrm{H}_{46} \mathrm{O}_{6} \mathrm{Na}$, 525.3192). In the ${ }^{1} \mathrm{H}$ NMR spectrum, the disappearance of the AX system signals deriving from 9,19-cyclopropane ring suggested a ring cleavage. The hydroxymethine proton at C-16 was not present in the ${ }^{1} \mathrm{H}$ NMR spectrum. In addition, a new doublet signal at $\delta 4.03$ was observed together with two olefinic protons $(\delta$ 5.46 and 5.68). In the ${ }^{13} \mathrm{C}$ NMR spectrum, apart from the C-3, C-6, C24 and C-25 oxygenated carbons, two additional signals at $\delta 72.3$ and 88.3 were detected. The ${ }^{13} \mathrm{C}$ NMR spectrum of $\mathbf{4}$ also exhibited four olefinic carbon resonances ( $\delta 128.4,134.2,136.8$ and 141.8) and a carbonyl signal at $\delta 221.4$. The combined use of DQF-COSY and HSQC spectra, allowed the assignment of two spin systems (Fig. 2): 'A' (H-3 $\left.\rightarrow \mathrm{H}_{2}-1\right)$ and ' $\mathrm{B}$ '( $\left.\mathrm{H}-5 \rightarrow \mathrm{H}_{2}-19\right)$. The spin system $A$ includes the $\mathrm{H}-3$ resonance $(\delta 3.73 \mathrm{~d}, J=5.6 \mathrm{~Hz})$ which showed correlation with $\mathrm{H}-2 \mathrm{~b}(\delta 1.74 \mathrm{~m})$, while the latter proton showed cross peak with $\mathrm{H}-2 \mathrm{a}(\delta 2.00 \mathrm{~m})$, which, in turn, coupled with both $\mathrm{H}_{2}-1$ protons ( $\delta 1.38 \mathrm{~m}$ and $1.58 \mathrm{~m}$ ). The second spin system (B) includes a methine proton at $\delta 1.61(\mathrm{~m}, \mathrm{H}-5)$ which showed correlation with the oxymethine proton at C- $6(\delta 4.54 \mathrm{dd}, J=10.3,3.4 \mathrm{~Hz})$ and from there to an olefinic methine proton at $\delta 5.46(\mathrm{dd}, J=3.5,1.3 \mathrm{~Hz}, \mathrm{H}-$ 7). The $\mathrm{H}-7$ proton showed ${ }^{5} \mathrm{~J}_{\mathrm{H}-\mathrm{H}}$ coupling with $\mathrm{H}-11$ through the conjugated double bond system $(\delta 5.68 \mathrm{~d}, J=5.5 \mathrm{~Hz})$ in the DQFCOSY spectrum. H-11 coupled with oxymethine proton at $\delta 4.03$ (d, $J=6.0 \mathrm{~Hz}, \mathrm{H}-12$ ) which, in turn, exhibited cross peaks with the $\mathrm{H}_{2}-19$ methylene protons $(\delta 2.67 \mathrm{~d}, J=14.3 \mathrm{~Hz} ; \delta 3.04 \mathrm{~d}, J=14.0 \mathrm{~Hz})$. Location of the olefinic double bonds was assigned from the correlations in the HMBC spectrum. The two signals ( $\delta 2.67$ and 3.04)
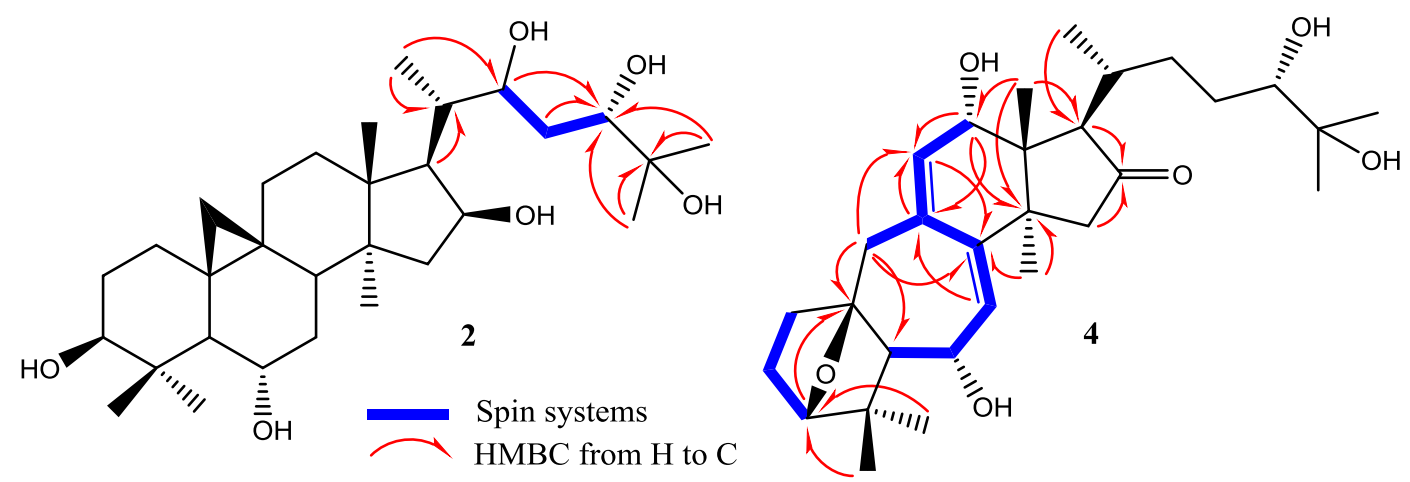

Fig. 2. The partial spin systems (COSY) and key long-range correlations (HMBC) of 2 and 4. 
were assigned to $\mathrm{H}_{2}-19$ based on the long-distance correlations in the HMBC spectrum ( $\delta 2.67$ to C-5, C-10, C-11, C-9 and C-8; $\delta 3.04$ to $\mathrm{C}-10, \mathrm{C}-11$ and $\mathrm{C}-9$ ) indicating a seven-membered $\mathrm{B}$ ring resulting from the cleavage of the cyclopropane ring. The long-distance correlations from $\mathrm{H}_{2}-19, \mathrm{H}-12$ and $\mathrm{H}-7$ to the quaternary carbon at $\delta 134.2$ revealed the location of the double bond between $\mathrm{C}-9$ and $\mathrm{C}-11$. The other trisubstituted double bond was positioned between C-7 and C- 8 based on the HMBC correlations from $\mathrm{H}-19 \mathrm{~b}, \mathrm{H}-11$ and $\mathrm{H}_{3}-30$ to the quaternary $141.8 \mathrm{ppm}$ signal. Additionally, the carbon signal at $\delta 221.4$ displayed long-range correlations with the protons of $\mathrm{H}_{2}-15$ and $\mathrm{H}-17$, implying the oxidation of $\mathrm{C}-16$ secondary alcohol to a ketone. On the other hand, a new signal observed at $\delta 4.03$, corresponding with a carbon at $72.3 \mathrm{ppm}$ in the HSQC spectrum, indicated an additional oxymethine group. The HMBC spectrum showed long-distance correlations from $\delta 4.03$ proton to C-9, C-11, C-14. Based on these findings, the new hydroxyl group was located at $\mathrm{C}-12$. The hydroxyl group at $\mathrm{C}-12$ was deduced to be $\alpha$-oriented on the basis of ROESY correlation of H-12 ( $\delta 4.03)$ with the beta oriented $\mathrm{H}_{3}-18(\delta 0.84)$. The carbon signal at $86.8 \mathrm{ppm}$ had long-range correlations with $\mathrm{H}_{3}-28$ and $\mathrm{H}_{3}-29$ in the HMBC spectrum, readily assigned to $\mathrm{C}-3$. Additionally, downfield shift of C-3 signal suggested that an oxygen bridge involving C-3 atom was present in the framework. Resemblance of the spectral data of 4 with those of previously reported compounds (Feng et al., 2015) together with the long-distance correlation of the quaternary carbon at $88.3 \mathrm{ppm}$ with $\mathrm{H}-3(\delta 3.73)$ provided evidence for the oxygen bridge between $\mathrm{C}-3$ and $\mathrm{C}-10$ carbons. The orientation of 3(10)epoxy bridge was confirmed by inspecting the ROESY spectrum of 4 and calculating its minimized energy conformer by MM2 molecular mechanics program. In the ROESY spectrum, $\mathrm{H}-3$ showed strong correlation with $\mathrm{H}_{3}-28(\delta 1.22)$, which in turn correlated with $\mathrm{H}-6 \beta$. Moreover, a weak nOe correlation between $\mathrm{H}-3$ and $\mathrm{H}_{3}-29$ was observed. The minimized energy conformer of $\mathbf{4}$ clearly showed that $\beta$-oriented 3(10)-epoxy bridge above the $A$ ring made $\mathrm{H}-3$ to lie in close proximity with $\mathrm{H}_{3}-28$ (2.45 $\AA$ ) instead of alpha oriented $\mathrm{H}_{3}-$ 29 (2.9 A) (see Supplementary information: Fig. S36). For the alphaoriented epoxy bridge, completely conflicting interatomic distances with the ROESY correlations were measured, revealing $3(10) \beta$ epoxy bridge. Thus, 4 was deduced to be $6 \alpha, 12 \alpha, 24(S), 25-$ tetrahydroxy-3(10) $\beta$-epoxy-9,10-seco-cycloartane-7,9(11)-dien16-one.

The compound 5 had a molecular formula of $\mathrm{C}_{31} \mathrm{H}_{50} \mathrm{O}_{5}$ based on the HR-MS data $\left(\mathrm{m} / \mathrm{z} 525.3566[\mathrm{M}+\mathrm{Na}]^{+}\right.$, calcd for $\mathrm{C}_{31} \mathrm{H}_{50} \mathrm{O}_{5} \mathrm{Na}$, 525.3555). An additional carbon suggested the insertion of a methyl group into the structure. When 1D NMR spectra of $\mathbf{5}$ were inspected, their similarities with those of $\mathbf{4}$ were acknowledged at once. Major differences between these two compounds were that the signals for the oxymethine at C-12 and the ketone resonance of $\mathrm{C}-16$ in 4 were missing, instead, additional signals for 0 -methyl group $\left(\delta_{\mathrm{H}}=3.33\right.$ and $\delta_{\mathrm{C}}=56.5$ ) were observed in $\mathbf{5}$ together with hydroxylated $\mathrm{C}(\mathrm{H})-16$ resonances as in the case of $\mathbf{1}$. The methoxy protons at $\delta 3.33$ showed an HMBC correlation with $\delta 79.2$ (C-6), suggesting that $O$-methylation occurred at C-6. Therefore, $\mathbf{5}$ was identified as $16 \beta, 24(S), 25$-trihydroxy-6 $\alpha$-methoxy-3(10) $\beta$-epoxy9,10-seco-cycloartane-7,9(11)-diene.

The HR-MS spectrum of $\mathbf{6}\left(\mathrm{m} / z 527.3370[\mathrm{M}+\mathrm{Na}]^{+}\right.$, calcd for $\mathrm{C}_{30} \mathrm{H}_{48} \mathrm{O}_{6} \mathrm{Na}, 527.3348$ ) supported a molecular formula of $\mathrm{C}_{30} \mathrm{H}_{48} \mathrm{O}_{6}$. The absence of 9,19-cyclopropane ring signals in the ${ }^{1} \mathrm{H}$ NMR spectrum suggested a ring cleavage as in $\mathbf{4}$ and $\mathbf{5}$. Five tertiary methyl group signals observed in the up-field region, implying a modification on one of the methyl groups compared to the starting compound. An AB system at $\delta 3.50$ and 3.76 confirmed the presence of a primary alcohol group. In the ${ }^{13} \mathrm{C}$ NMR spectrum, apart from the already expected carbon signals, two oxygen-bearing methine carbons ( $\delta 68.7$ and 89.1), two olefinic carbons ( $\delta 131.2$ and 132.5) and a ketone carbonyl signal ( $\delta$ 221.9) were observed in the lowfield region. In the HSQC spectrum, no correlation were observed between any protons with the carbons at $\delta 131.2$ and 132.5, justifying a tetrasubstituted olefinic system. These olefinic signals were attributed to C-9 and C-8, respectively, according to the HMBC correlations from $\mathrm{H}-7, \mathrm{H}-12$ and $\mathrm{H}-19$ to the signal at $\delta 131.2$, and from $\mathrm{H}-7$ and $\mathrm{H}-30$ to $\delta 132.5$ resonance. The ${ }^{3} \mathrm{~J}-\mathrm{HMBC}$ correlations of the oxymethylene protons at $\delta 3.50$ and 3.76 with the C-8, C-14 and C-15 signals revealed the position of oxygenated methyl at C30. Finally, the HMBC correlation between $\mathrm{H}-15$ with the carbon resonance at $\delta 221.9$ confirmed the location of the ketone group to be $\mathrm{C}-16$. As a result, the structure of $\mathbf{6}$ was established as $6 \alpha, 24(S), 25,30$-tetrahydroxy-3(10)ß-epoxy-9,10-seco-cycloartane8(9)-en-16-one.

The molecular formula of 7 was established as $\mathrm{C}_{30} \mathrm{H}_{50} \mathrm{O}_{6}$ by HRMS analysis $\left(m / z 529.3522[\mathrm{M}+\mathrm{Na}]^{+}\right.$, calcd for $\mathrm{C}_{30} \mathrm{H}_{50} \mathrm{O}_{6} \mathrm{Na}$, 529.3505). In the ${ }^{1} \mathrm{H}$ NMR spectrum, the signals of a cyclopropyl ring were not detected, implying a ring cleavage. In addition, the hydroxymethine proton at C-16 was lost in the ${ }^{1} \mathrm{H}$ NMR spectrum compared to the starting compound. In the ${ }^{13} \mathrm{C}$ NMR spectrum, a signal observed at $\delta 68.8$ correlated with two proton resonances at $\delta 3.51$ and 3.44 (AB system) in the HSQC spectrum, indicating the presence of an oxymethylene group. On the other hand, a carbonyl signal at $\delta 221.8$ was noticed from the ${ }^{13} \mathrm{C}$ NMR spectrum together with two olefinic carbon signals ( $\delta 132.3$ and 136.6). In the HSQC spectrum, no correlations of any protons with the olefinic carbons indicated a tetrasubstituted olefinic system. The double bond was located between C-9 and C-10 on the basis of the HMBC correlations from $\mathrm{H}-1$ and $\mathrm{H}-5$ to the $\delta 132.3$ signal, as well as from $\mathrm{H}-1$ to the $\delta 136.6$ signal. Furthermore, the HMBC correlation between $\mathrm{H}_{2}-$ 12 and $\mathrm{C}-19$ suggested that the cyclopropane methylene carbon (C19) migrated over to $C-11$. The similarity between the spectral data of $\mathbf{6}$ and previously reported biotransformation products of cycloartanes not only supported our assumption but also helped us to deduce the relative stereochemistry of $\mathrm{C}-19$ to be $\beta$ (Kuban et al., 2010, 2013; Yang et al., 2012). Additionally, the long-range correlations of $\mathrm{H}_{2}-15$ and $\mathrm{H}-17$ with the carbonyl carbon at $\delta 221.8$ confirmed the oxidation of $\mathrm{C}-16(\mathrm{OH})$ to a ketone. Consequently, metabolite 7 was deduced to be $3 \beta, 6 \alpha, 16 \beta, 19,24(S), 25-$ hexahydroxy-ranunculan-9(10)-en-16-one.

The ${ }^{1} \mathrm{H}$ and ${ }^{13} \mathrm{C}$ NMR spectra of $\mathbf{8}$ were in agreement with those reported for $3 \beta, 6 \alpha, 16 \beta, 19,24(S), 25$-hexahydroxy-ranunculan-9(10)ene, previously obtained from the biotransformation study of CCG with Cunninghamella blakesleeana NRRL 1369 (Bedir et al., 2015).

\section{Conclusion}

Despite their promising potential as biocatalysts, the use of plant-associated endophytic fungi to transform plant originated secondary metabolites have been scarcely explored. After preliminary screenings, microbial transformation studies were carried out using 15 endophytic fungi isolated from different parts of Astragalus plants. Based on the analytical scale results, Alternaria eureka 1E1BL1, a fungal species never exploited as a biocatalyst, was selected for further biotransformation studies. Preparative scale incubation of CCG with this endophytic fungus afforded eight metabolites (1-8). A. eureka 1E1BL1 was found to be capable of hydroxylation, oxidation, epoxidation, $O$-methylation, ringexpansion and methyl migration reactions on the cycloartane nucleus. These modifications resulted in the formation of the compounds that would be difficult or impossible to prepare by conventional synthetic methods.

Compounds 1, 2 and 3 were monohydroxylated analogs of CCG having hydroxyl groups at $\mathrm{C}-12, \mathrm{C}-17$ and $\mathrm{C}-22$ positions, respectively, produced by $\mathrm{P} 450$-catalyzed monooxygenation reactions. 
Unusually, the fungus did monohydroxylate CCG at C-17 and C-22 positions. The presence of a hydroxyl group at aforementioned positions has been rarely reported in the literature for triterpenoidal saponins (Lu et al., 2010; Shaymaa et al., 2016; Yoshikawa et al., 2000). To the best of our knowledge, 17- and 22hydroxylation of cycloartane nucleus by microbial transformation was never reported.

Apart from the monohydroxylation reactions, A. eureka 1E1BL1 catalyzed ring expansion and epoxidation reactions on CCG $(\mathbf{4}, 5$ and $\mathbf{6}$ ) to form 3(10)ß-epoxy-9,10-seco-cycloartane structure. The microbial-catalysis of the $\mathrm{B}$ ring expansion reactions have been observed in the transformation of cycloastragenol to give 9,10-secocycloartane skeleton by the fungus Syncephalastrum racemosum AS 3.264 (Feng et al., 2015; Yang et al., 2012). However, a reaction mechanism was not proposed for this unique biotransformation. In Fig. 4, a tentative reaction pathway is shown for compounds 4-6. As cyclopropane ring behaves like a double bond in nature, C-1, C-5, $\mathrm{C}-8$ and $\mathrm{C}-11$ positions are subject to allylic rearrangements. A hydrogen abstraction from C-11 or C- 8 by $\mathrm{P} 450$ enzyme results in carbocation formation, which in turn leads to migration of $\mathrm{C}-9 / \mathrm{C}-10$ bond of the cyclopropane ring to yield a seven membered ring (9,10-seco-cycloartane), C-8(C-9) or C-9(C-11) double bond and a carbocation at $\mathrm{C}-10$ position. As a result of this transformation, the ring A favors boat conformation, which rearranges $\mathrm{C}-3(\mathrm{OH})$ and $\mathrm{C}$ 10 to lie in close proximity (ca. 1.9-2.0 Å, calculated by minimized energy conformers). This adjacent localization facilitates the nucleophilic attack of $\mathrm{C}-3(\mathrm{OH})$ to the carbocation $(\mathrm{C}-10)$ to give 3(10) $\beta$-epoxy framework.

In addition, compounds $\mathbf{7}$ and $\mathbf{8}$ were the rearrangement products of CCG resulting from the cleavage of 9,19-cyclopropane ring followed by methyl migration. This unique transformation was reported previously in the biotransformation of CA and CCG by Cunninghamella blakesleeana NRRL 1369, Syncephalastrum racemosum AS 3.264 and Alternaria alternata AS 3.4578 (Bedir et al., 2015; Feng et al., 2015; Kuban et al., 2010; Yang et al., 2012).

Consequently, this is the first report in Astragalus sapogenin chemistry utilizing Astragalus originated endophytic fungi. The results of this study prove that biotransformation using endophytic fungi is an efficient tool for the structural modification of secondary metabolites to expand compound libraries and prediction of tentative mammalian metabolites of traditionally used crude drugs.

\section{Experimental}

\subsection{General experimental procedures}

Mass spectrometry experiments were carried out on an Agilent 1200/6530 Instrument - HRTOFMS. NMR spectra were recorded on Varian Oxford AS400 and Bruker DRX-500 instruments. The chemical shifts were measured relative to the residual solvent peak and are expressed in $\delta(\mathrm{ppm})$ and the coupling constant $(J)$ are reported in Hertz (Hz). Silica gel 60 (70-230 mesh, Merck), Sephadex LH-20 (GE Healthcare Life Sciences) and RP-18 (Chromabond C18, Macherey-Nagel) were used for column chromatography. TLC analyses were carried out on Silica gel 60 F254 (Merck) and RP-18 F254s (Merck) plates. Spots were visualized under UV light and by spraying with $20 \% \mathrm{H}_{2} \mathrm{SO}_{4} /$ water reagent followed by heating at $105^{\circ} \mathrm{C}$ for $1-2 \mathrm{~min}$.

\subsection{Plant material and the starting compound}

Astragalus angustifolius and Astragalus condensatus (Fabaceae) were collected from Spil Mountain (38 33.965’ N, 27²4.400’ E), Manisa, Turkey in June 2013, and identified by Serdar Gökhan Şenol (Department of Biology, Faculty of Science, Ege University, Turkey). The plant samples were put into plastic bags and transported to the

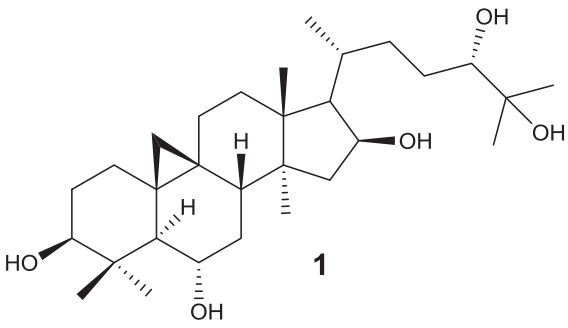

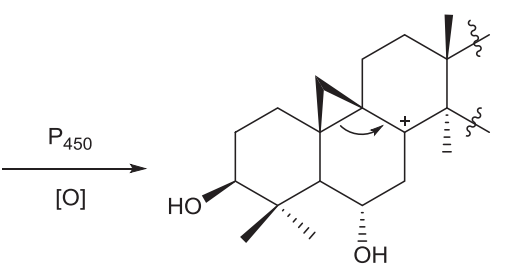

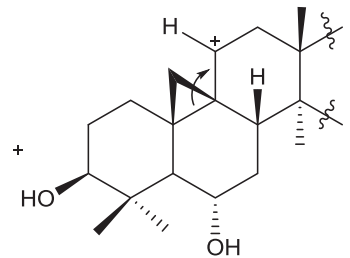
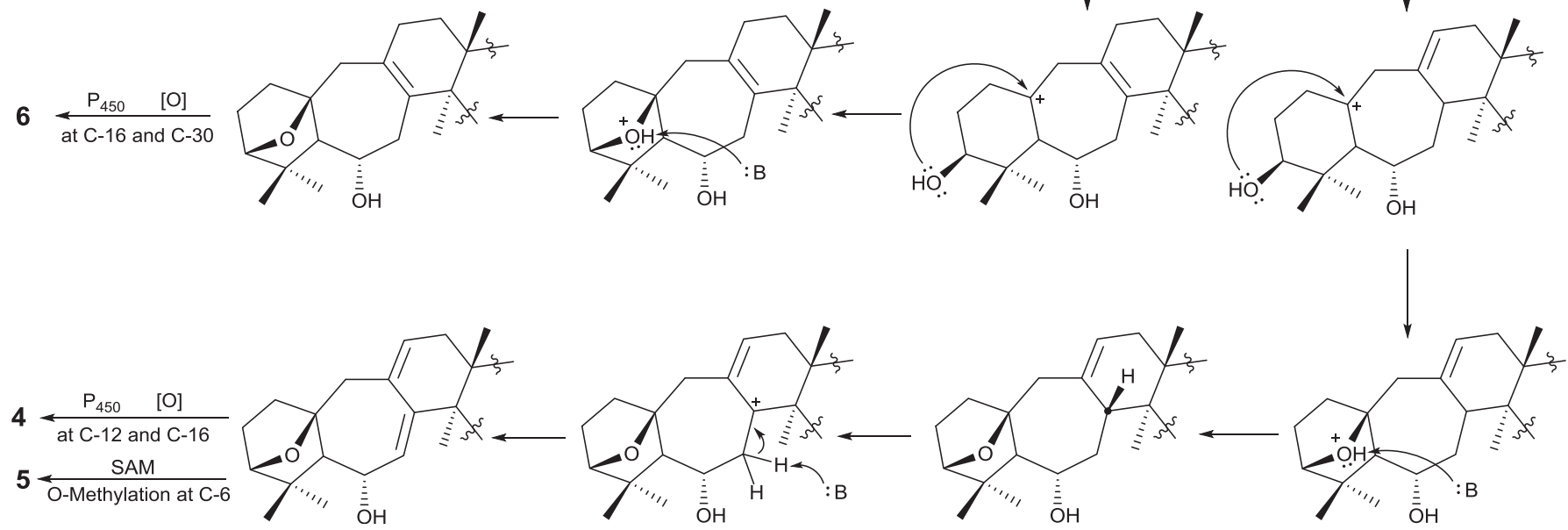

Fig. 4. The plausible mechanism for the transformation of compounds $\mathbf{4}, \mathbf{5}$ and $\mathbf{6}$. 
laboratory within $24 \mathrm{~h}$. The starting compound, cyclocanthogenol (CCG), was donated by Bionorm Natural Products Ltd. (İzmir, Turkey).

\subsection{Fungal material}

The fungal endophytes used in this study were isolated from fresh and healthy tissues of Astragalus species. The plant samples were washed thoroughly in running tap water followed by distilled water to remove any dirt and the adhering soil particles. Then, the plant materials were cut into small pieces and were subjected to surface sterilization under aseptic condition. The samples were surface-sterilized by sequential immersion in $70 \%$ ethanol for $5 \mathrm{~min}$, \%3-5 sodium hypochlorite for $5 \mathrm{~min}$, and $70 \%$ ethanol for $30 \mathrm{~s}$. Finally, the surface-sterilized plant tissues were rinsed in sterile distilled water three times for $1 \mathrm{~min}$, then air dried under a laminar-flow hood. The outer tissues were removed from the airdried plant samples with the help of a flame-sterilized scalpel and the inner tissues were cut into small fragments. The tissue fragments were then placed in Petri dishes containing potato dextrose agar (PDA), malt extract agar (MEA), Rose-Bengal Chloramphenicol (RBC) agar and water agar (WA) and incubated at $25^{\circ} \mathrm{C}$ until fungal growth started. To confirm the success of surface sterilization procedure, $100 \mu \mathrm{L}$ aliquots of water from the last washing step were inoculated on PDA and incubated under the same conditions in parallel. The plates were monitored every day to check the growth of endophytic fungi. The hyphal tips that emerged from the tissue fragments were isolated and subcultured onto PDA media. Subsequently, the pure fungal cultures were transferred on PDA slants and stored at $4{ }^{\circ} \mathrm{C}$.

The endophytic fungus 1E1BL1 was identified by the identification service at Deutsche Sammlung von Mikroorganismen und Zellkulturen GmbH (DSMZ), Braunschweig, Germany. The identification of the fungal isolate was done on the basis of the sequence of rDNA ITS, which is the first common DNA-barcode for fungi (Schoch et al., 2012). Additionally, amplification and sequencing of the large subunit of rDNA (LSU) and the TEF1 gene were performed (Woudenberg et al., 2013). The assembled DNA sequences were compared with those in GenBank, MycoID and various databases as well as with the type species of Alternaria eureka (Pleosporaceae).

\subsection{Microbial transformation procedures}

The microbial transformation process was conducted at two scales; analytical and preparative. One-stage fermentation protocol was followed where CCG was fed to the biotransformation media $72 \mathrm{~h}$ after the inoculation (Kuban et al., 2010). On analytical scale, the mycelial agar plugs ( $8 \mathrm{~mm}$ in diameter) from 5-day-old fungal cultures grown on PDA plate were inoculated into $250 \mathrm{ml}$ Erlenmeyer flask containing $50 \mathrm{ml}$ biotransformation medium (2\% glucose, $0.5 \%$ yeast extract, $0.5 \% \mathrm{NaCl}, 0.5 \% \mathrm{Na}_{2} \mathrm{HPO}_{4}, 0.5 \%$ peptone $(\mathrm{w} / \mathrm{v})$ ) adjusted to $\mathrm{pH}$ 6.0. After inoculation, the flasks were incubated on a rotary shaker at $180 \mathrm{rpm}, 25^{\circ} \mathrm{C}$ for $72 \mathrm{~h}$. CCG $(10 \mathrm{mg}$ dissolved in $500 \mu \mathrm{l}$ of DMSO) was added to 72-h-old cultures, which were then incubated at $25^{\circ} \mathrm{C}, 180 \mathrm{rpm}$ for 21 days. The samples were taken on days $0,2,4,7,10,14,17,21$ and centrifuged at

Table 1

${ }^{1} \mathrm{H}$ NMR data of metabolites $\mathbf{1 - 7}\left(400 \mathrm{MHz}\right.$, in $\left.\mathrm{CD}_{3} \mathrm{OD}\right)$.

\begin{tabular}{|c|c|c|c|c|c|c|c|}
\hline \multirow[t]{2}{*}{$\mathrm{H}$} & 1 & 2 & \multirow[b]{2}{*}{$\delta_{\mathrm{H}}(\mathrm{ppm}), J(\mathrm{~Hz})$} & \multirow{2}{*}{$\frac{4}{\delta_{\mathrm{H}}(\mathrm{ppm}), J(\mathrm{~Hz})}$} & \multirow{2}{*}{$\frac{\mathbf{5}}{\delta_{\mathrm{H}}(\mathrm{ppm}), J(\mathrm{~Hz})}$} & \multirow{2}{*}{$\frac{\mathbf{6}}{\delta_{\mathrm{H}}(\mathrm{ppm}), J(\mathrm{~Hz})}$} & \multirow{2}{*}{$\frac{7}{\delta_{\mathrm{H}}(\mathrm{ppm}), J(\mathrm{~Hz})}$} \\
\hline & $\delta_{\mathrm{H}}(\mathrm{ppm}), J(\mathrm{~Hz})$ & $\delta_{\mathrm{H}}(\mathrm{ppm}), J(\mathrm{~Hz})$ & & & & & \\
\hline 1 & $1.28 \mathrm{~m}, 1.66 \mathrm{~m}$ & $1.26 \mathrm{~m}, 1.58 \mathrm{~m}$ & $1.25 \mathrm{~m}, 1.57 \mathrm{~m}$ & $1.38 \mathrm{~m}, 1.58 \mathrm{~m}$ & $1.32 \mathrm{~m}, 1.49 \mathrm{~m}$ & $1.45 \mathrm{~m}, 1.76 \mathrm{~m}$ & $1.83 \mathrm{~m}, 2.31 \mathrm{~d}(14.4)$ \\
\hline 2 & $1.62 \mathrm{~m}, 1.74 \mathrm{~m}$ & $1.61 \mathrm{~m}, 1.70 \mathrm{~m}$ & $1.61 \mathrm{~m}, 1.71 \mathrm{~m}$ & $1.74 \mathrm{~m}, 2.00 \mathrm{~m}$ & $1.72 \mathrm{~m}, 1.97 \mathrm{~m}$ & $1.67 \mathrm{~m}, 2.05 \mathrm{~m}$ & $1.47 \mathrm{~m}, 1.88 \mathrm{~m}$ \\
\hline 3 & $3.23 \mathrm{dd}(10.8,4.6)$ & $3.32 \mathrm{dd}(10.9,4.4)$ & $3.22 \mathrm{dd}(4.4,10.9)$ & $3.73 \mathrm{~d}(5.6)$ & $3.72 \mathrm{~d}(5.6)$ & $3.83 \mathrm{~d}(7.4)$ & $3.36 \mathrm{dd}(4.5,11.2)$ \\
\hline 4 & & & & & & & \\
\hline 5 & $1.34 \mathrm{~m}$ & $1.33 \mathrm{~m}$ & $1.34 \mathrm{~d}(9.9)$ & $1.61 \mathrm{~m}$ & $1.57 \mathrm{~d}(10.6)$ & $1.50 \mathrm{~d}(9.6)$ & $1.80 \mathrm{~m}$ \\
\hline 6 & $3.41 \mathrm{~m}$ & $3.45 \mathrm{dt}(9.8,3.3)$ & $3.44 \mathrm{~m}$ & $4.54 \mathrm{dd}(10.3,3.4)$ & $4.05 \mathrm{dd}(10.3,2.8)$ & $3.69 \operatorname{td}(10.1,2.7)$ & 3.76 ddd $(11.6,7.2,4.5)$ \\
\hline 7 & $1.35 \mathrm{~m}, 1.41 \mathrm{~m}$ & $1.38 \mathrm{~m}, 1.46 \mathrm{~m}$ & $1.35 \mathrm{~m}, 1.41 \mathrm{~m}$ & $5.46 \mathrm{dd}(3.5,1.3)$ & 5.36 brs. & $2.21 \mathrm{~m}, 2.57 \mathrm{~m}$ & $1.35 \mathrm{~m}, 1.57 \mathrm{~m}$ \\
\hline 8 & $1.64 \mathrm{~m}$ & $1.81 \mathrm{dd}(12.1,3.9)$ & $1.78 \mathrm{~m}$ & & & & $2.45 \mathrm{~d}(10.9)$ \\
\hline \multicolumn{8}{|c|}{ 等, } \\
\hline \multicolumn{8}{|c|}{10} \\
\hline 11 & $\begin{array}{l}1.75 \mathrm{dd}(9.3,13.3), \\
2.0 \mathrm{dd}(13.3,5.1)\end{array}$ & $1.19 \mathrm{~m}, 1.99 \mathrm{~m}$ & $1.16 \mathrm{~m}, 2.09 \mathrm{~m}$ & $5.68 \mathrm{~d}(5.5)$ & 5.47 brs. & $2.20 \mathrm{~m}, 2.27 \mathrm{~m}$ & $3.04 \mathrm{~m}$ \\
\hline 12 & $3.82 \mathrm{dd}(3.9,5.9)$ & $1.65 \mathrm{~m}(2 \mathrm{H})$ & $1.44 \mathrm{~m}, 2.11 \mathrm{~m}$ & $4.03 \mathrm{~d}(6.0)$ & 2.18 brs. $(2 \mathrm{H})$ & $1.95 \mathrm{~m}, 2.20 \mathrm{~m}$ & $1.51 \mathrm{~m}, 1.86 \mathrm{~m}$ \\
\hline \multicolumn{8}{|c|}{13} \\
\hline \multicolumn{8}{|c|}{14} \\
\hline 15 & $1.41 \mathrm{~m}, 2.02 \mathrm{~m}$ & $1.43 \mathrm{~m}, 2.04 \mathrm{~m}$ & $\begin{array}{l}1.41 \mathrm{~m}, 2.15 \mathrm{dd}(13.2 \text {, } \\
8.5)\end{array}$ & $\begin{array}{l}2.10 \mathrm{~d}(17.7), 2.45 \mathrm{~d} \\
(17.6)\end{array}$ & $\begin{array}{l}1.74 \mathrm{~m}, 2.10 \mathrm{dd}(12.9 \text {, } \\
8.1)\end{array}$ & $2.46 \mathrm{~s}(2 \mathrm{H})$ & $1.97 \mathrm{~d}$ (19.7), $2.19 \mathrm{~d}(18.4)$ \\
\hline 16 & $\begin{array}{l}4.46 \text { ddd }(5.4,7.9 \text {, } \\
7.9)\end{array}$ & $\begin{array}{l}4.46 \text { ddd }(5.6,7.6 \text {, } \\
7.6)\end{array}$ & 4.19 dd $(5.8,8.2)$ & & 4.55 ddd $(5.6,7.7,8.0)$ & & \\
\hline 17 & $2.30 \mathrm{dd}(11.0,7.8)$ & $2.08 \mathrm{~m}$ & & $2.94 \mathrm{~d}(7.3)$ & $1.70 \mathrm{~m}$ & $2.72 \mathrm{~m}$ & $2.37 \mathrm{~d}(7.1)$ \\
\hline 18 & $1.10 \mathrm{~s}$ & $1.18 \mathrm{~s}$ & $1.23 \mathrm{~s}$ & $0.84 \mathrm{~s}$ & $0.87 \mathrm{~s}$ & $1.07 \mathrm{~s}$ & $1.07 \mathrm{~s}$ \\
\hline 19 & $0.47 \mathrm{~d}, 0.50 \mathrm{~d}(4.5)$ & $\begin{array}{l}0.38 \mathrm{~d}(4.3), 0.53 \mathrm{~d} \\
(4.1)\end{array}$ & $\begin{array}{l}0.43 \mathrm{~d}(4.2), 0.51 \mathrm{~d} \\
(4.2)\end{array}$ & $\begin{array}{l}2.67 \mathrm{~d}(14.3), 3.04 \mathrm{~d} \\
(14.0)\end{array}$ & $\begin{array}{l}2.55 \mathrm{~d}(13.9), 3.02 \mathrm{~d} \\
(13.6)\end{array}$ & $\begin{array}{l}2.29 \mathrm{~d}(14.9), 2.75 \mathrm{~d} \\
(14.8)\end{array}$ & $\begin{array}{l}3.51 \mathrm{dd}(10.7,5.0), 3.44 \mathrm{t} \\
(11.1)\end{array}$ \\
\hline 20 & $1.92 \mathrm{~m}$ & $2.11 \mathrm{~m}$ & $2.04 \mathrm{~m}$ & $1.73 \mathrm{~m}$ & $1.94 \mathrm{~m}$ & $1.84 \mathrm{~m}$ & $1.76 \mathrm{~m}$ \\
\hline 21 & $1.07 \mathrm{~d}(6.6)$ & $0.92 \mathrm{~d}(6.4)$ & $0.94 \mathrm{~d}(6.0)$ & $1.09 \mathrm{~d}(6.8)$ & $0.97 \mathrm{~d}(6.4)$ & $1.09 \mathrm{~d}(6.8)$ & $1.06 \mathrm{~d}(6.8)$ \\
\hline 22 & $1.43 \mathrm{~m}, 1.82 \mathrm{~m}$ & $4.04 \mathrm{dd}(7.3,5.8)$ & $1.29 \mathrm{~m}, 1.71 \mathrm{~m}$ & $1.56 \mathrm{~m}, 1.90 \mathrm{~m}$ & $1.23 \mathrm{~m}, 1.80 \mathrm{~m}$ & $1.59 \mathrm{~m}, 1.92 \mathrm{~m}$ & $1.78 \mathrm{~m}, 2.74 \mathrm{~m}$ \\
\hline 23 & $1.29 \mathrm{~m}, 1.61 \mathrm{~m}$ & $1.58 \mathrm{~m}, 1.77 \mathrm{~m}$ & $1.41 \mathrm{~m}, 1.62 \mathrm{~m}$ & $1.41 \mathrm{~m}, 1.59 \mathrm{~m}$ & $1.43 \mathrm{~m}, 1.63 \mathrm{~m}$ & $1.45 \mathrm{~m}, 1.64 \mathrm{~m}$ & $1.39 \mathrm{~m}, 1.58 \mathrm{~m}$ \\
\hline $\begin{array}{l}24 \\
25\end{array}$ & $3.40 \mathrm{~m}$ & $3.53 \mathrm{dd}(10.5,2.2)$ & $3.40 \mathrm{~m}$ & $3.30 \mathrm{~m}$ & $3.38 \mathrm{dd}(10.9,1.9)$ & $3.36 \mathrm{~m}$ & $3.28 \mathrm{~m}$ \\
\hline 26 & $1.15 \mathrm{~s}$ & $1.16 \mathrm{~s}$ & $1.15 \mathrm{~s}$ & $1.15 \mathrm{~s}$ & $1.15 \mathrm{~s}$ & $1.21 \mathrm{~s}$ & $1.14 \mathrm{~s}$ \\
\hline 27 & $1.17 \mathrm{~s}$ & $1.22 \mathrm{~s}$ & $1.16 \mathrm{~s}$ & $1.17 \mathrm{~s}$ & $1.17 \mathrm{~s}$ & $1.24 \mathrm{~s}$ & $1.17 \mathrm{~s}$ \\
\hline 28 & $1.24 \mathrm{~s}$ & $1.22 \mathrm{~s}$ & $1.24 \mathrm{~s}$ & $1.22 \mathrm{~s}$ & $1.15 \mathrm{~s}$ & $1.20 \mathrm{~s}$ & $1.17 \mathrm{~s}$ \\
\hline 29 & $0.95 \mathrm{~s}$ & $0.95 \mathrm{~s}$ & $0.96 \mathrm{~s}$ & $1.12 \mathrm{~s}$ & $1.07 \mathrm{~s}$ & $1.18 \mathrm{~s}$ & $0.68 \mathrm{~s}$ \\
\hline 30 & $1.02 \mathrm{~s}$ & $0.99 \mathrm{~s}$ & $1.28 \mathrm{~s}$ & $1.32 \mathrm{~s}$ & $0.97 \mathrm{~s}$ & $\begin{array}{l}3.50 \mathrm{~d}(11.4), 3.76 \mathrm{~d} \\
(11.4)\end{array}$ & $0.96 \mathrm{~s}$ \\
\hline $1^{\prime}$ & & & & & $3.33 \mathrm{~s}$ & & \\
\hline
\end{tabular}


Table 2

${ }^{13} \mathrm{C}$ NMR data of metabolites $\mathbf{1}-\mathbf{7}\left(100 \mathrm{MHz}\right.$, in $\left.\mathrm{CD}_{3} \mathrm{OD}\right)$.

\begin{tabular}{|c|c|c|c|c|c|c|c|}
\hline \multirow[t]{2}{*}{ C } & 1 & 2 & 3 & 4 & 5 & 6 & 7 \\
\hline & $\delta_{\mathrm{C}}(\mathrm{ppm})$ & $\delta_{\mathrm{C}}(\mathrm{ppm})$ & $\delta_{\mathrm{C}}(\mathrm{ppm})$ & $\delta_{\mathrm{C}}(\mathrm{ppm})$ & $\delta_{\mathrm{C}}(\mathrm{ppm})$ & $\delta_{\mathrm{C}}(\mathrm{ppm})$ & $\delta_{\mathrm{C}}(\mathrm{ppm})$ \\
\hline 1 & $33.7 \mathrm{t}$ & $33.5 \mathrm{t}$ & $33.5 \mathrm{t}$ & $38.8 \mathrm{t}$ & $38.5 \mathrm{t}$ & $40.3 \mathrm{t}$ & $31.9 \mathrm{t}$ \\
\hline 2 & $31.1 \mathrm{t}$ & $31.1 \mathrm{t}$ & $31.1 \mathrm{t}$ & $25.8 \mathrm{t}$ & $25.7 \mathrm{t}$ & $26.5 \mathrm{t}$ & $32.8 \mathrm{t}$ \\
\hline 3 & $79.4 \mathrm{~d}$ & $79.5 \mathrm{~d}$ & $79.4 \mathrm{~d}$ & $86.8 \mathrm{~d}$ & $86.8 \mathrm{~d}$ & $87.9 \mathrm{~d}$ & $78.4 \mathrm{~d}$ \\
\hline 4 & $42.7 \mathrm{~s}$ & $42.7 \mathrm{~s}$ & $42.7 \mathrm{~s}$ & $48.3 \mathrm{~s}$ & $48.0 \mathrm{~s}$ & $46.5 \mathrm{~s}$ & $42.5 \mathrm{~s}$ \\
\hline 5 & $54.6 \mathrm{~d}$ & $54.5 \mathrm{~d}$ & $54.7 \mathrm{~d}$ & $63.6 \mathrm{~d}$ & $62.8 \mathrm{~d}$ & $64.9 \mathrm{~d}$ & $57.8 \mathrm{~d}$ \\
\hline 6 & $70.3 \mathrm{~d}$ & $69.8 \mathrm{~d}$ & $70.3 \mathrm{~d}$ & $68.9 \mathrm{~d}$ & $79.2 \mathrm{~d}$ & $68.2 \mathrm{~d}$ & $68.5 \mathrm{~d}$ \\
\hline 7 & $39.3 \mathrm{t}$ & $38.9 \mathrm{t}$ & $39.3 \mathrm{t}$ & $136.8 \mathrm{~d}$ & $130.5 \mathrm{~d}$ & $40.7 \mathrm{t}$ & $37.4 \mathrm{t}$ \\
\hline 8 & $49.6 \mathrm{~d}$ & $48.8 \mathrm{~d}$ & $51.0 \mathrm{~d}$ & $141.8 \mathrm{~s}$ & $145.7 \mathrm{~s}$ & $132.5 \mathrm{~s}$ & $40.9 \mathrm{~d}$ \\
\hline 9 & $22.0 \mathrm{~s}$ & $22.2 \mathrm{~s}$ & $22.2 \mathrm{~s}$ & $134.2 \mathrm{~s}$ & $132.8 \mathrm{~s}$ & $131.2 \mathrm{~s}$ & $132.3 \mathrm{~s}$ \\
\hline 10 & $30.7 \mathrm{~s}$ & $30.7 \mathrm{~s}$ & $31.1 \mathrm{~s}$ & $88.3 \mathrm{~s}$ & $88.6 \mathrm{~s}$ & $89.1 \mathrm{~s}$ & $136.6 \mathrm{~s}$ \\
\hline 11 & $39.7 \mathrm{t}$ & $27.0 \mathrm{t}$ & $27.4 \mathrm{t}$ & $128.4 \mathrm{~d}$ & $127.6 \mathrm{~d}$ & $30.76 \mathrm{t}$ & $39.3 \mathrm{~d}$ \\
\hline 12 & $73.7 \mathrm{~d}$ & $34.0 \mathrm{t}$ & $28.0 \mathrm{t}$ & $72.3 \mathrm{~d}$ & $39.3 \mathrm{t}$ & $30.82 \mathrm{t}$ & $33.7 \mathrm{t}$ \\
\hline 13 & $50.5 \mathrm{~s}$ & $47.8 \mathrm{~s}$ & $51.6 \mathrm{~s}$ & $48.7 \mathrm{~s}$ & $45.0 \mathrm{~s}$ & $47.0 \mathrm{~s}$ & $42.7 \mathrm{~s}$ \\
\hline 14 & $47.3 \mathrm{~s}$ & $46.5 \mathrm{~s}$ & $47.1 \mathrm{~s}$ & $46.9 \mathrm{~s}$ & $50.9 \mathrm{~s}$ & $51.0 \mathrm{~s}$ & $46.5 \mathrm{~s}$ \\
\hline 15 & $50.2 \mathrm{t}$ & $48.5 \mathrm{t}$ & $49.3 \mathrm{t}$ & $49.8 \mathrm{t}$ & $45.3 \mathrm{t}$ & $42.1 \mathrm{t}$ & $49.8 \mathrm{t}$ \\
\hline 16 & $73.2 \mathrm{~d}$ & $73.1 \mathrm{~d}$ & $82.5 \mathrm{~d}$ & $221.4 \mathrm{~s}$ & $72.8 \mathrm{~d}$ & $221.9 \mathrm{~s}$ & $221.8 \mathrm{~s}$ \\
\hline 17 & $49.8 \mathrm{~d}$ & $53.3 \mathrm{~d}$ & $89.3 \mathrm{~s}$ & $57.2 \mathrm{~d}$ & $57.0 \mathrm{~d}$ & $62.7 \mathrm{~d}$ & $63.2 \mathrm{~d}$ \\
\hline 18 & $18.5 \mathrm{q}$ & $19.2 \mathrm{q}$ & $21.0 \mathrm{q}$ & $18.6 \mathrm{q}$ & $17.2 \mathrm{q}$ & $19.2 \mathrm{q}$ & $18.1 \mathrm{q}$ \\
\hline 19 & $32.3 \mathrm{t}$ & $31.8 \mathrm{t}$ & $32.6 \mathrm{t}$ & $41.5 \mathrm{t}$ & $41.4 \mathrm{t}$ & $39.1 \mathrm{t}$ & $68.8 \mathrm{t}$ \\
\hline 20 & $29.4 \mathrm{~d}$ & $35.4 \mathrm{~d}$ & $35.7 \mathrm{~d}$ & $32.8 \mathrm{~d}$ & $30.0 \mathrm{~d}$ & $33.0 \mathrm{~d}$ & $32.7 \mathrm{~d}$ \\
\hline 21 & $16.0 \mathrm{q}$ & $13.4 \mathrm{q}$ & $14.2 \mathrm{q}$ & $18.5 \mathrm{q}$ & $18.6 \mathrm{q}$ & $19.6 \mathrm{q}$ & $19.5 \mathrm{q}$ \\
\hline 22 & $33.8 \mathrm{t}$ & $75.3 \mathrm{~d}$ & $30.5 \mathrm{t}$ & $33.6 \mathrm{t}$ & $33.8 \mathrm{t}$ & $33.9 \mathrm{t}$ & $29.4 \mathrm{t}$ \\
\hline 23 & $28.5 \mathrm{t}$ & $34.9 \mathrm{t}$ & $29.2 \mathrm{t}$ & $29.9 \mathrm{t}$ & $28.5 \mathrm{t}$ & $30.0 \mathrm{t}$ & $29.9 \mathrm{t}$ \\
\hline 24 & $78.3 \mathrm{~d}$ & $79.1 \mathrm{~d}$ & $78.0 \mathrm{~d}$ & $79.5 \mathrm{~d}$ & $78.5 \mathrm{~d}$ & $79.5 \mathrm{~d}$ & $79.4 \mathrm{~d}$ \\
\hline 25 & $73.8 \mathrm{~s}$ & $73.5 \mathrm{~s}$ & $73.8 \mathrm{~s}$ & $73.8 \mathrm{~s}$ & $73.8 \mathrm{~s}$ & $73.8 \mathrm{~s}$ & $73.8 \mathrm{~s}$ \\
\hline 26 & $25.4 \mathrm{q}$ & $25.1 \mathrm{q}$ & $25.4 \mathrm{q}$ & $25.1 \mathrm{q}$ & $25.4 \mathrm{q}$ & $25.1 \mathrm{q}$ & $25.1 \mathrm{q}$ \\
\hline 27 & $25.5 \mathrm{q}$ & $25.6 \mathrm{q}$ & $25.4 \mathrm{q}$ & $25.6 \mathrm{q}$ & $25.4 \mathrm{q}$ & $25.6 \mathrm{q}$ & $25.6 \mathrm{q}$ \\
\hline 28 & $29.0 \mathrm{q}$ & $28.8 \mathrm{q}$ & $29.0 \mathrm{q}$ & $23.4 \mathrm{q}$ & $25.4 \mathrm{q}$ & $24.9 \mathrm{q}$ & $26.5 \mathrm{q}$ \\
\hline 29 & $16.0 \mathrm{q}$ & $15.8 \mathrm{q}$ & $15.9 \mathrm{q}$ & $25.3 \mathrm{q}$ & $25.2 \mathrm{q}$ & $27.2 \mathrm{q}$ & $14.8 \mathrm{q}$ \\
\hline 30 & $21.9 \mathrm{q}$ & $20.5 q$ & $23.0 \mathrm{q}$ & $28.7 \mathrm{q}$ & $26.1 \mathrm{q}$ & $68.7 \mathrm{t}$ & $18.1 \mathrm{q}$ \\
\hline $1^{\prime}$ & & & & & $56.5 \mathrm{~s}$ & & \\
\hline
\end{tabular}

$10000 \mathrm{rpm}$ for $10 \mathrm{~min}$. Then supernatants were extracted with EtOAc ( $1 \mathrm{ml})$ and analyzed by TLC. Control experiments were conducted in the absence of either CCG or the fungus. Preparative scale biotransformation was performed in $1000 \mathrm{ml}$ Erlenmeyer flasks each containing $300 \mathrm{ml}$ of biotransformation medium using $1080 \mathrm{mg}$ CCG, and incubated at $25^{\circ} \mathrm{C}, 180 \mathrm{rpm}$ for 10 days. After incubation period, the mycelia were filtered on a Buchner funnel, the combined filtrate was extracted with EtOAc ( $5.5 \mathrm{~L} \mathrm{x} \mathrm{2),} \mathrm{and} \mathrm{the}$ organic phase was dried over anhydrous $\mathrm{Na}_{2} \mathrm{SO}_{4}$, followed by filtration and evaporation in vacuo.

\subsection{Isolation and purification}

After evaporation of the solvent in vacuo, $2.5 \mathrm{~g}$ of extract was obtained due to the presence of unconsumed nutrients, as well as undesired metabolic by-products of the fungus. The EtOAc extract $(2.5 \mathrm{~g})$ was first chromatographed on a Sephadex-LH 20 column ( $70 \mathrm{~g}$ ) and eluted with $100 \% \mathrm{MeOH}$, which provided 80 fractions. Fractions 38 to 48 were pooled together for further purification. This fraction ( $1.90 \mathrm{~g}$ ) was subjected to a reversed-phase column (C$18,100 \mathrm{~g})$, using $\mathrm{MeOH}-\mathrm{H}_{2} \mathrm{O}(45: 55$ to $90: 10)$ and $100 \% \mathrm{MeOH}$ yielding 295 fractions. Fraction $66-80(78 \mathrm{mg})$ was submitted to silica gel column $(50 \mathrm{~g})$ chromatography with the solvent system $\mathrm{CHCl}_{3}-\mathrm{MeOH}-\mathrm{H}_{2} \mathrm{O}$ (90:10:0.5 to $\left.82.5: 17.5: 0.5\right)$ to give 3 subfractions. Subfraction $1(20 \mathrm{mg})$ was further purified on a silica gel column (10 g) using cyclohexane-EtOAc-MeOH (10:10:2) to afford metabolite 6 (5 mg). Fraction 94-100 (122 mg) was chromatographed over silica gel column $(60 \mathrm{~g})$ with the solvent system $\mathrm{CHCl}_{3}-\mathrm{MeOH}-\mathrm{H}_{2} \mathrm{O}(90: 10: 0.5$ to $85: 15: 0.5)$ to provide 1 (22 $\mathrm{mg}$ ) and $2(5.5 \mathrm{mg})$. Fraction $133-155(82 \mathrm{mg})$ was subjected to a silica gel column (15 g), and eluted with $\mathrm{CHCl}_{3}-\mathrm{MeOH}-\mathrm{H}_{2} \mathrm{O}$ (90:10:0.5 to $85: 15: 0.5)$ to give $8 \mathrm{mg}$ of 4 . Fraction $169-185$ (91 mg) was purified on a silica gel column (50 g) using $\mathrm{CHCl}_{3}-\mathrm{MeOH}-\mathrm{H}_{2} \mathrm{O}$ (90:10:0.5 to $85: 15: 0.5)$ to give metabolite 3 (22.2 mg). Fraction 186-200 (135 mg) was further fractionated over silica gel column (55 g) with the solvent system $\mathrm{CHCl}_{3}-\mathrm{MeOH}-\mathrm{H}_{2} \mathrm{O}$ (90:10:0.5 to $82.5: 17.5: 0.5)$ to give $20 \mathrm{mg}$ of metabolite 8. Fraction 201-210 (84 mg) was chromatographed over silica gel column (50 g) with the solvent system $\mathrm{CHCl}_{3}-\mathrm{MeOH}-\mathrm{H}_{2} \mathrm{O}(90: 10: 0.5$ to $85: 15: 0.5)$ to give 4 subfractions. Subfraction $4(14 \mathrm{mg})$ was further purified on silica gel column $(10 \mathrm{~g})$ using $\mathrm{CHCl}_{3}-\mathrm{MeOH}-\mathrm{H}_{2} \mathrm{O}$ (90:10:0.5 to $85: 15: 0.5)$ to afford 7 (6.5 mg). Fraction 285-295 (30 mg) was further applied to a silica gel column $(30 \mathrm{~g})$ using $\mathrm{CHCl}_{3}-\mathrm{MeOH}$ (97.5:2.5 to $90: 10$ ) as eluent to purify $8 \mathrm{mg}$ of metabolite $\mathbf{5}$.

\subsection{Spectral data of $\mathbf{1}-\mathbf{7}$}

Metabolite 1: ${ }^{1} \mathrm{H}$ NMR $\left(\mathrm{CD}_{3} \mathrm{OD}, 400 \mathrm{MHz}\right)$ : see Table $1 ;{ }^{13} \mathrm{C}$ NMR $\left(\mathrm{CD}_{3} \mathrm{OD}, 100 \mathrm{MHz}\right)$ : see Table 2; HR-MS: $m / z 531.3664[\mathrm{M}+\mathrm{Na}]^{+}$ $\left(\mathrm{C}_{30} \mathrm{H}_{52} \mathrm{O}_{6} \mathrm{Na}\right.$, calcd. 531.3661).

Metabolite 2: ${ }^{1} \mathrm{H}$ NMR $\left(\mathrm{CD}_{3} \mathrm{OD}, 400 \mathrm{MHz}\right)$ : see Table $1 ;{ }^{13} \mathrm{C}$ NMR $\left(\mathrm{CD}_{3} \mathrm{OD}, 100 \mathrm{MHz}\right)$ : see Table 2; HR-MS: $\mathrm{m} / z$ $531.3679[\mathrm{M}+\mathrm{Na}]^{+}$ $\left(\mathrm{C}_{30} \mathrm{H}_{52} \mathrm{O}_{6} \mathrm{Na}\right.$, calcd. 531.3661).

Metabolite 3: ${ }^{1} \mathrm{H}$ NMR $\left(\mathrm{CD}_{3} \mathrm{OD}, 400 \mathrm{MHz}\right)$ : see Table $1 ;{ }^{13} \mathrm{C}$ NMR $\left(\mathrm{CD}_{3} \mathrm{OD}, 100 \mathrm{MHz}\right)$ : see Table 2; HR-MS: $m / z 531.3672[\mathrm{M}+\mathrm{Na}]^{+}$ $\left(\mathrm{C}_{30} \mathrm{H}_{52} \mathrm{O}_{6} \mathrm{Na}\right.$, calcd. 531.3661).

Metabolite 4: ${ }^{1} \mathrm{H}$ NMR $\left(\mathrm{CD}_{3} \mathrm{OD}, 400 \mathrm{MHz}\right)$ : see Table $1 ;{ }^{13} \mathrm{C}$ NMR $\left(\mathrm{CD}_{3} \mathrm{OD}, 100 \mathrm{MHz}\right)$ : see Table 2; HR-MS: $m / z 525.3206[\mathrm{M}+\mathrm{Na}]^{+}$ $\left(\mathrm{C}_{30} \mathrm{H}_{46} \mathrm{O}_{6} \mathrm{Na}\right.$, calcd. 525.3192).

Metabolite 5: ${ }^{1} \mathrm{H}$ NMR $\left(\mathrm{CD}_{3} \mathrm{OD}, 400 \mathrm{MHz}\right)$ : see Table $1 ;{ }^{13} \mathrm{C}$ NMR $\left(\mathrm{CD}_{3} \mathrm{OD}, 100 \mathrm{MHz}\right)$ : see Table 2; HR-MS: $\mathrm{m} / z$ 525.3566 [M+Na] ${ }^{+}$ $\left(\mathrm{C}_{31} \mathrm{H}_{50} \mathrm{O}_{5} \mathrm{Na}\right.$, calcd. 525.3555).

Metabolite 6: ${ }^{1} \mathrm{H}$ NMR $\left(\mathrm{CD}_{3} \mathrm{OD}, 400 \mathrm{MHz}\right)$ : see Table $1 ;{ }^{13} \mathrm{C}$ NMR $\left(\mathrm{CD}_{3} \mathrm{OD}, 100 \mathrm{MHz}\right)$ : see Table 2; HR-MS: $\mathrm{m} / z 527.3370[\mathrm{M}+\mathrm{Na}]^{+}$ $\left(\mathrm{C}_{30} \mathrm{H}_{48} \mathrm{O}_{6} \mathrm{Na}\right.$, calcd. 527.3348).

Metabolite 7: ${ }^{1} \mathrm{H}$ NMR $\left(\mathrm{CD}_{3} \mathrm{OD}, 400 \mathrm{MHz}\right)$ : see Table $1 ;{ }^{13} \mathrm{C}$ NMR $\left(\mathrm{CD}_{3} \mathrm{OD}, 100 \mathrm{MHz}\right)$ : see Table 2; HR-MS: $\mathrm{m} / z 529.3522[\mathrm{M}+\mathrm{Na}]^{+}$ $\left(\mathrm{C}_{30} \mathrm{H}_{50} \mathrm{O}_{6} \mathrm{Na}\right.$, calcd. 529.3505).

\section{Acknowledgements}

This project was supported by The Scientific and Technological Research Council of Turkey (TUBITAK, Project No: 114Z958). We are very grateful to Bionorm Natural Products for providing cyclocanthogenol.

\section{Appendix A. Supplementary data}

Supplementary data related to this article can be found at https://doi.org/10.1016/j.phytochem.2018.04.006.

\section{References}

Bedir, E., Kula, C. Öner, Ö. Altas, M. Tă̆ Ö., Öngen, G., 2015. Microbial transformation of Astragalus sapogenins using Cunninghamella blakesleeana NRRL 1369 and Glomerella fusarioides ATCC 9552. J. Mol. Catal. B Enzym 115, 29-34. Bianchini, L.F., Arruda, M.F.C., Vieira, S.R., Campelo, P.M.S., Gregio, A.M.T. Rosa, E.A.R., 2015. Microbial biotransformation to obtain new antifungals. Front. Microbiol. 6, 1-12

Borges, K.B., Borges, W.d S., Durán-Patrón, R., Pupo, M.T., Bonato, P.S., Collado, I.G., 2009. Stereoselective biotransformations using fungi as biocatalysts. Tetrahedron Asymmetry 20, 385-397.

Carballeira, J.D., Quezada, M.A., Hoyos, P., Simeó, Y., Hernaiz, M.J., Alcantara, A.R., Sinisterra, J.V., 2009. Microbial cells as catalysts for stereoselective red-ox reactions. Biotechnol. Adv. 27, 686-714.

de Carvalho, C.C.C.R., 2016. Whole cell biocatalysts: essential workers from Nature to the industry. Microb. Biotechnol.

de Carvalho, C.C.C.R., 2011. Enzymatic and whole cell catalysis: finding new strategies for old processes. Biotechnol. Adv. 29, 75-83.

Çalış, I., Yürüker, A., Tașdemir, D., Wright, A.D., Sticher, O., Luo, Y.D., Pezzuto, J.M., 1997. Cycloartane triterpene glycosides from the roots of Astragalus 
98

G. Ekiz et al. / Phytochemistry 151 (2018) 91-98

melanophrurius. Planta Med. 63, 183-186.

Feng, L.M., Ji, S., Qiao, X., Li, Z.W., Lin, X.H., Ye, M., 2015. Biocatalysis of cycloastragenol by Syncephalastrum racemosum and Alternaria alternata to discover anti-aging derivatives. Adv. Synth. Catal. 357, 1928-1940.

Harley, C.B., Khar, S.P., Ramaseshan, M., Ramiya, P., Pirot, Z.Z., Fauce, S., Lin, T., 2010 Compositions and methods for increasing telomerase activity. U. S. Patent 20100292197 A1, November 18, 2010.

Kuban, M., Öngen, G., Bedir, E., 2010. Biotransformation of cycloastragenol by Cunninghamella blakesleeana NRRL 1369 resulting in a novel framework. Org. Lett. 12, 4252-4255.

Kuban, M., Öngen, G., Khan, I.A., Bedir, E., 2013. Microbial transformation of cycloastragenol. Phytochemistry 88, 99-104.

Lam, K.S., 2009. Application of whole-cell biotransfotmation in the pharmaceutical industry. In: Tao, J., Lin, G.-Q., Liese, A. (Eds.), Biocatalysis for the Pharmaceutical Industry: Discovery, Development, and Manufacturing. John Wiley \& Sons (Asia) Pte Ltd, Singapore, pp. 214-227, 324p.

Lu, L., Chen, J.-C., Song, H.-J., Li, Y., Nian, Y., Qiu, M.-H., 2010. Five new triterpene bisglycosides with acyclic side chains from the rhizomes of Cimicifuga foetida $\mathrm{L}$. Chem. Pharm. Bull. (Tokyo) 58, 729-733.

Ludwig-Müller, J., 2015. Plants and endophytes: equal partners in secondary metabolite production? Biotechnol. Lett. 37, 1325-1334.

Nalbantsoy, A., Nesil, T., Erden, S., Çalış, İ., Bedir, E., 2011. Adjuvant effects of Astragalus saponins macrophyllosaponin B and astragaloside VII. J. Ethnopharmacol. 134, 897-903.

Özipek, M., Dönmez, A.A., Çalıș, İ., Brun, R., Rüedi, P., Tasdemir, D., 2005. Leishmanicidal cycloartane-type triterpene glycosides from Astragalus oleifolius. Phytochemistry 66, 1168-1173.

Pimentel, M.R., Molina, G., Dionísio, A.P., Maróstica Junior, M.R., Pastore, G.M., 2011. The use of endophytes to obtain bioactive compounds and their application in biotransformation process. Biotechnol. Res. Int. 2011, 576286.

Schoch, C.L., Seifert, K.A., Huhndorf, S., Robert, V., Spouge, J.L., Levesque, C.A., Chen, W., Consortium, F.B., 2012. Nuclear ribosomal internal transcribed spacer (ITS) region as a universal DNA barcode marker for Fungi. Proc. Natl. Acad. Sci. 109, 6241-6246.

Shah, S.A.A., Tan, H.L., Sultan, S., Faridz, M.A.B.M., Shah, M.A.B.M., Nurfazilah, S., Hussain, M., 2014. Microbial-catalyzed biotransformation of multifunctional triterpenoids derived from phytonutrients. Int. J. Mol. Sci.

Shaymaa, M.M., Backheet, E.Y., Bayoumi, S.A., Ross, S.A., 2016. New cycloartane saponin and monoterpenoid glucoindole alkaloids from Mussaenda luteola. Fitoterapia 110, 129-134.

Tă̆, Ö., Çağır, A., Khan, I.A., Bedir, E., 2012. Cleavage of ring A and formation of an unusual nor-triterpene skeleton via the Baeyer-Villiger reaction. Tetrahedron Lett. 53, 5864-5867.

Tao, J., Xu, J.H., 2009. Biocatalysis in development of green pharmaceutical processes. Curr. Opin. Chem. Biol. 13, 43-50.

Vincken, J.P., Heng, L., de Groot, A., Gruppen, H., 2007. Saponins, classification and occurrence in the plant kingdom. Phytochemistry 68, 275-297.

Wang, Y., Dai, C.C., 2011. Endophytes: a potential resource for biosynthesis, biotransformation, and biodegradation. Ann. Microbiol. 61, 207-215.

Woudenberg, J.H.C., Groenewald, J.Z., Binder, M., Crous, P.W., 2013. Alternaria redefined. Stud. Mycol. 75, 171-212.

Yang, W.Z., Ye, M., Huang, F.X., He, W.N., Guo, D.A., 2012. Biocatalysis of cycloastragenol by filamentous fungi to produce unexpected triterpenes. Adv. Synth. Catal. 354, 527-539.

Yoshikawa, K., Katsuta, S., Mizumori, J., Arihara, S., 2000. Four cycloartane triterpenoids and six related saponins from Passiflora edulis. J. Nat. Prod. 63, 1229-1234. 